\title{
Influence of the Biofield Energy Healing Treatment on the Physicochemical and Thermal Properties of Metronidazole
}

Keywords: Metronidazole; The trivedi effect ${ }^{\oplus}$; Consciousness energy healing treatment; Particle size; Surface area; PXRD; DSC; TGA/DTG

\begin{abstract}
Metronidazole is an antibiotic useful for the treatment of vaginosis, trichomoniasis, giardiasis, etc., which are caused by the bacteria and parasites. The research work aimed to estimate the impact of the Trivedi Effect ${ }^{-}$-Consciousness Energy Healing Treatment on the physicochemical and thermal properties of metronidazoleusing modern analytical techniques. The test sample metronidazole was divided into control and treated sample. The control sample did not receive Biofield Energy Treatment; whereas the treated sample received the Biofield Treatment remotely by a renowned Biofield Energy Healer, Dahryn Trivedi. The particle size values were significantly increased by $14.37 \%\left(d_{10}\right), 9.94 \%\left(d_{50}\right), 7.9 \%\left(d_{90}\right)$, and $9.41 \%[D(4,3)]$; hence, the specific surface area was significantly decreased by $10.58 \%$ in the treated sample compared with the control sample. The PXRD peak intensities and crystallite sizes were significantly altered ranging from $-97.25 \%$ to $401.64 \%$ and $-63.08 \%$ to $344.35 \%$, respectively, however, average crystallite size was significantly increased by $24.4 \%$ in the treated sample compared with the control sample. The latent heat of fusion and latent heat of decomposition were significantly increased by $7.64 \%$ and $12.13 \%$, respectively in the treated sample compared to the control sample. The total weight loss was decreased by $1.34 \%$; however, the residue amount was significantly increased by $76.46 \%$ in the treated sample compared with the control sample. The Biofield Energy Treatment might generate a new polymorphic form of metronidazole which would offer better powder flow ability and more thermos table compared with the control sample. The treated metronidazole would be very useful in designing better pharmaceutical formulations that might offer better therapeutic responses against the bacterial infections in the vagina, stomach, liver, skin, joints, brain, and respiratory tract, aspiration pneumonia, fungating wounds, rosacea abdominal infections, periodontitis, amoebiasis, etc.
\end{abstract}

\section{Introduction}

Metronidazoleis an antibiotic and useful against the diseases caused by the anaerobic bacteria and some of the parasites. It selectively blocks nucleic acid synthesis by disrupting the DNA of microbial cells and the parasites resulting in their death. It has the relatively little effect on human cells or aerobic bacteria, but this function only occurs in anaerobic cells $[1,2]$. It is used to treat bacterial infections in vagina (trichomoniasis), stomach infections (pseudomembranous colitis, giardiasis), liver, skin, joints (pelvic inflammatory disease, abscess of the ovaries and fallopian tubes), brain, and respiratory tract, aspiration pneumonia, fungating wounds, rosacea, intraabdominal infections, lung abscess, periodontitis, amoebiasis, oral infections, and other infections caused by the anaerobic organisms such as Bacteroides, Clostridium, Helicobacter pylori, Fusobacterium, Dracunculus, Peptostreptococcus, and Prevotella species, etc. [2-5]. It is also used for the treatment of infections caused by Giardia in domestic

\section{Journal of}

\section{Analytical \& Molecular Techniques}

\author{
Trivedi $D^{1}$, Trivedi $\mathbf{M K}^{1}$, Branton $\mathrm{A}^{1}$, Nayak $\mathbf{G}^{1}$ and \\ Jana $\mathbf{S}^{2^{*}}$ \\ ${ }^{1}$ Trivedi Global, Inc., Henderson, USA \\ ${ }^{2}$ Trivedi Science Research Laboratory Pvt. Ltd., Bhopal, India
}

Address for Correspondence

Jana S, Trivedi Science Research Laboratory Pvt. Ltd., Bhopal, India. Tel: +91-022-25811234; E-mail: publication@trivedieffect.com

Submission: 05 September, 2018

Accepted: 08 October, 2018

Published: 10 October, 2018

Copyright: () 2018 Trivedi D, et al. This is an open access article distributed under the Creative Commons Attribution License, which permits unrestricted use, distribution, and reproduction in any medium, provided the original work is properly cited.

animals [2,6]. Side effects of metronidazole therapy are nausea, headache, dizziness, diarrhea, loss of appetite, weight loss, abdominal cramp, vomiting, metallic taste in the mouth, thrombophlebitis, hypersensitivity reactions, stomatitis, glossitis, dark urine, leucopenia, neutropenia, vaginal dryness, peripheral neuropathy, central nervous system toxicity, decrease of libido, and paraesthesia etc. [2,7]. The taste of metronidazole is bitter, so it is dispensed in the in the form of metronidazole benzoate in liquid suspension. It is also delivered in the form of the capsule, tablet, and intravenous injection [7-9]. It is hazardous on skin contact, eye contact, inhalation, and ingestion. Metronidazole is slightly soluble in water, alcohol, chloroform, dilute acid, and dimethylformamide $[10,11]$.

The physicochemical properties play a crucial role in dissolution, absorption, and bioavailability profile of the pharmaceutical or nutraceutical compounds in the human body [12]. The impact of the Trivedi Effect ${ }^{\oplus}$-Consciousness Energy Healing Treatment has been proven scientifically altering the physicochemical properties such as crystallite size, particle size, surface area, thermal properties, and bioavailability profile of pharmaceutical and nutraceutical compounds [13-17]. The Trivedi Effect ${ }^{\circ}$ is natural and the only scientifically proven phenomenon in which a person can harness this inherently intelligent energy from the universe and transmit it anywhere on the planet through the mediation of neutrinos [18]. A unique infinite and para-dimensional electromagnetic field energy field exists surrounding the body of every living organism called the "Biofield". Biofield based Energy Therapies have been reported with significantly beneficial outcomes against various disease conditions [19]. The National Institutes of Health/National Center for Complementary and Alternative Medicine (NIH/NCCAM) recommend and included the Energy therapy under the Complementary and Alternative Medicine (CAM) category along with Ayurvedic medicine, essential oils, traditional Chinese herbs and medicines, naturopathy, homeopathy, Tai Chi, Qi Gong, chiropractic/osteopathic manipulation, Reiki, healing touch, deep breathing, yoga, meditation, special diets, massage, 
Citation: Trivedi D, Trivedi MK, Branton A, Nayak G, Jana S. Influence of the Biofield Energy Healing Treatment on the Physicochemical and Thermal Properties of Metronidazole. J Analyt Molecul Tech 2018;3(1): 7

progressive relaxation, relaxation techniques, guided imagery, acupuncture, acupressure, movement therapy, hypnotherapy, pilates, Rolfing structural integration, mindfulness, cranial sacral therapy, aromatherapy, and applied prayer. The CAM has been accepted by the most of the U.S. population because of many advantages [20,21]. The Trivedi Effect ${ }^{\circ}$-Consciousness Energy Healing Treatment has huge potential to alter the physicochemical, structural, and behavioral properties of organic compounds, metals, polymers, ceramics [22-26], inhibition of the microorganisms [27,28], kill cancer cells [29,30], and also improve the overall productivity of crops $[31,32]$. Seeing all these surprising results, this study was designed to evaluate the impact of the Trivedi Effect ${ }^{\oplus}$-Consciousness Energy Healing Treatment on the physicochemical, thermal, and behavioral properties of metronidazole powder sample using Particle Size Analysis (PSA), Powder X-Ray Diffraction (PXRD), Differential Scanning Calorimetry (DSC), and Thermogravimetric Analysis (TGA)/Differential Thermogravimetric Analysis (DTG).

\section{Materials and Methods}

\section{Chemicals and reagents}

Metronidazole (2-Methyl-5-nitroimidazole-1-ethanol) was purchased from Tokyo Chemical Industry Co., Ltd., Japan. All other chemicals used during the experiments were of analytical grade available in India.

\section{Consciousness energy healing treatment strategies}

Metronidazole considered as the test sample for the experiment was divided into two equal parts. One part of the test sample was treated with the Trivedi Effect ${ }^{\oplus}$-Consciousness Energy Healing Treatment remotely under standard laboratory conditions for 3 minutes and known as the Biofield Energy Treated sample. This Biofield Energy Treatment was provided through the healer's unique energy transmission process by the renowned Biofield Energy Healer, Dahryn Trivedi, USA, to the sample of metronidazole. However, the second part of the test sample was termed as a control sample (no Biofield Energy Treatment was provided). Further, the control sample was treated with a "sham" healer for the comparison purpose. The "sham" healer did not have any knowledge about the Biofield Energy Treatment. After treatment, the Biofield Energy Treated and untreated samples were both kept in sealed conditions for the characterization using PSA, PXRD, DSC, and TGA techniques.

\section{Characterization}

Particle size analysis (PSA): The PSA of metronidazole powder sample was conducted on Malvern Mastersizer 2000, from the UK with a detection range between $0.01 \mu \mathrm{m}$ to $3000 \mu \mathrm{m}$ using wet method [33,34]. The sample unit (Hydro MV) was filled with a dispersant medium (sunflower oil) and the stirrer operated at $2500 \mathrm{rpm}$. The PSA analysis of metronidazole powder sample was performed to obtain the average particle size distribution. Where $d(0.1) \mu \mathrm{m}, \mathrm{d}(0.5) \mu \mathrm{m}$, $\mathrm{d}(0.9) \mu \mathrm{m}$ represent particle diameter corresponding to $10 \%, 50 \%$, and $90 \%$ of the cumulative distribution. $\mathrm{D}(4,3)$ represents the average mass-volume diameter, and SSA is the specific surface area $\left(\mathrm{m}^{2} / \mathrm{g}\right)$. The calculations were done by using software Mastersizer Ver. 5.54. at below $10 \%$ level $\left(\mathrm{d}_{10}\right), 50 \%$ level $\left(\mathrm{d}_{50}\right), 90 \%$ level $\left(\mathrm{d}_{90}\right)$, and $\mathrm{D}(4,3)$ was calculated using the following equation 1 :

$$
\% \text { change in particle size }=\frac{\left[\mathrm{d}_{\text {Treated }}-\mathrm{d}_{\text {Control }}\right]}{\mathrm{d}_{\text {Control }}} \times 100
$$

Where $\mathrm{d}_{\text {Control }}$ and $\mathrm{d}_{\text {Treated }}$ are the particle sizes $(\mu \mathrm{m})$ at below $10 \%$ level $\left(\mathrm{d}_{10}\right), 50 \%$ level $\left(\mathrm{d}_{50}\right)$, and $90 \%$ level $\left(\mathrm{d}_{90}\right)$ of the control and the Biofield Energy Treated samples, respectively.

The percent change in surface area $(S)$ was calculated using the following equation 2 :

$\%$ change in surface area $=\frac{\left[\mathrm{S}_{\text {Treated }}-\mathrm{S}_{\text {Control }}\right]}{\mathrm{S}_{\text {Control }}} \times 100$

Where $\mathrm{S}_{\text {Control }}$ and $\mathrm{S}_{\text {Treated }}$ are the surface area of the control and the Biofield Energy Treated metronidazole powder sample, respectively.

Powder X-ray diffraction (PXRD) analysis: The PXRD analysis of metronidazole powder sample was performed with the help of Rigaku MiniFlex-II Desktop X-ray diffractometer (Japan) [35,36]. The $\mathrm{Cu}$ Ka radiation source tube output voltage used was $30 \mathrm{kV}$, and tube output current were $15 \mathrm{~mA}$. Scans were performed at room temperature. The average size of individual crystallites was calculated from PXRD data using the Scherrer's formula

$$
\mathrm{G}=\mathrm{k} \lambda / \beta \cos \theta
$$

Where $\mathrm{k}$ is the equipment constant (0.94), $\mathrm{G}$ is the crystallite size in $\mathrm{nm}, \lambda$ is the radiation wavelength $(0.154056 \mathrm{~nm}$ for Kal emission), $\beta$ is the full-width at half maximum (FWHM), and $\theta$ is the Bragg angle [37].

The percent change in crystallite size $(\mathrm{G})$ of metronidazolewas calculated using the following equation 3 :

$\%$ change in crystallite size $=\frac{\left[\mathrm{G}_{\text {Treated }}-\mathrm{G}_{\text {Control }}\right]}{\mathrm{G}_{\text {Control }}} \times 100$

Where $\mathrm{G}_{\text {Control }}$ and $\mathrm{G}_{\text {Treated }}$ are the crystallite size of the control and the Biofield Energy Treated samples, respectively.

Differential scanning calorimetry (DSC): The DSC analysis of metronidazole powder sample was performed with the help of DSC Q200, TA instruments. A sample of $\sim 1-3 \mathrm{mg}$ was loaded into the aluminium sample pan at a heating rate of $10^{\circ} \mathrm{C} / \mathrm{min}$ from $30^{\circ} \mathrm{C}$ to $350^{\circ} \mathrm{C}[33,34]$. The $\%$ change in melting point $(\mathrm{T})$ was calculated using the following equation 4 :

$\%$ change in melting point $=\frac{\left[\mathrm{T}_{\text {Treated }}-\mathrm{T}_{\text {Control }}\right]}{\mathrm{T}_{\text {Control }}} \times 100$

Where $\mathrm{T}_{\text {Control }}$ and $\mathrm{T}_{\text {Treated }}$ are the melting point of the control and the Biofield Energy Treated samples, respectively.

The percent change in the latent heat of fusion $(\Delta \mathrm{H})$ was calculated using the following equation 5 :

$$
\% \text { change in latent heat of fusion }=\frac{\left[\Delta \mathrm{H}_{\text {Treated }}-\Delta \mathrm{H}_{\text {Control }}\right]}{\Delta \mathrm{H}_{\text {Control }}} \times 100
$$

The percent change in particle size (d) for Metronidazole powder 

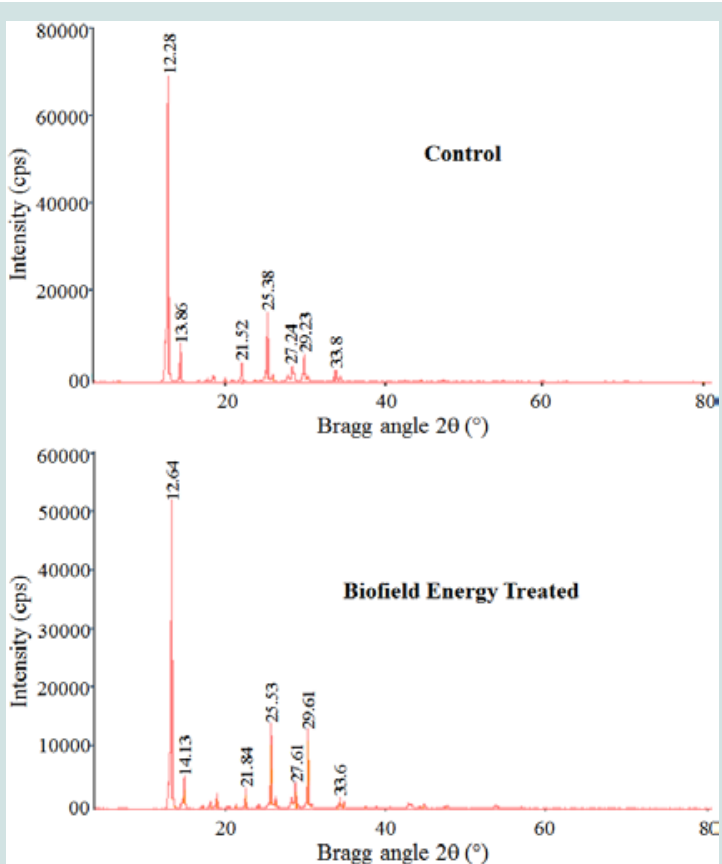

Figure 1: PXRD diffractograms of the control and the Biofield Energy Treated metronidazole powder sample.

Table 1: Particle size distribution of the control and the Biofield Energy Treated metronidazole powder sample.

\begin{tabular}{|c|c|c|c|c|c|}
\hline Parameter & $\mathbf{d}_{10}(\boldsymbol{\mu m})$ & $\mathbf{d}_{\mathbf{5 0}}(\boldsymbol{\mu m})$ & $\mathbf{d}_{\mathbf{9 0}}(\boldsymbol{\mu m})$ & $\mathbf{D}(\mathbf{4}, \mathbf{3})(\boldsymbol{\mu m})$ & $\mathbf{S S A}\left(\mathbf{m}^{2} / \mathbf{g}\right)$ \\
\hline Control & 126.72 & 268.42 & 493.05 & 290.73 & 0.0293 \\
\hline Biofield Treated & 144.92 & 295.1 & 531.98 & 318.08 & 0.0262 \\
\hline Percent change* $(\%)$ & 14.37 & 9.94 & 7.9 & 9.41 & -10.58 \\
\hline
\end{tabular}

Where $\Delta \mathrm{H}_{\text {Control }}$ and $\Delta \mathrm{H}_{\text {Treated }}$ are the latent heat of fusion of the control and the Biofield Energy Treated metronidazole, respectively.

Thermal gravimetric analysis (TGA)/ Differential thermogravimetric analysis (DTG): TGA/DTG thermo grams of metronidazole powder sample were obtained with the help of TGA Q50TA instruments. The sample of $\sim 3-6 \mathrm{mg}$ was loaded to the platinum crucible at a heating rate of $10{ }^{\circ} \mathrm{C} / \mathrm{min}$ from $25^{\circ} \mathrm{C}$ to 1000 ${ }^{\circ} \mathrm{C}$ with the recent literature $[33,34]$. The $\%$ change in Weight loss (W) was calculated using the following equation 6 :

$\%$ change in weight loss $=\frac{\left[\mathrm{W}_{\text {Treated }}-\mathrm{W}_{\text {Control }}\right]}{\mathrm{W}_{\text {Control }}} \times 100$

Where $\mathrm{W}_{\text {Control }}$ and $\mathrm{W}_{\text {Treated }}$ are the weight loss of the control and the Biofield Energy Treated metronidazole powder sample, respectively.

The $\%$ change in maximum thermal degradation temperature $\left(\mathrm{T}_{\max }\right)(\mathrm{M})$ was calculated using the following equation 7 :

$$
\% \text { change in } \operatorname{Tmax}(\mathrm{M})=\frac{\left[\mathrm{M}_{\text {Treated }}-\mathrm{M}_{\text {Control }}\right]}{\mathrm{M}_{\text {Control }}} \times 100
$$

Where $\mathrm{M}_{\text {Control }}$ and $\mathrm{M}_{\text {Treated }}$ are the $\mathrm{T}_{\max }$ values of the control and the Biofield Energy Treated metronidazole powder sample, respectively.

\section{Results and Discussion}

\section{Particle size analysis (PSA)}

The particle size analysis of both the control and the Biofield Energy Treated metronidazole powder samples were performed, and the calculated data are presented in Table 1 . The particle size values of the control powder sample at $\mathrm{d}_{10}, \mathrm{~d}_{50}, \mathrm{~d}_{90}$, and $\mathrm{D}(4,3)$ were 126.72 $\mu \mathrm{m}, 268.42 \mu \mathrm{m}, 493.05 \mu \mathrm{m}$, and $290.75 \mu \mathrm{m}$, respectively. Similarly, the particle sizes of the Biofield Energy Treated powder sample at $\mathrm{d}_{10}, \mathrm{~d}_{50}, \mathrm{~d}_{90}$, and $\mathrm{D}(4,3)$ were $144.92 \mu \mathrm{m}, 295.1 \mu \mathrm{m}, 531.98 \mu \mathrm{m}$, and $318.08 \mu \mathrm{m}$, respectively. The particle size values in the Biofield Energy Treated metronidazole powder sample were significantly increased by $14.37 \%, 9.94 \%, 7.9 \%$, and $9.41 \%$ at $\mathrm{d}_{10}, \mathrm{~d}_{50}, \mathrm{~d}_{90}$, and $\mathrm{D}(4,3)$, respectively compared to the control sample. The specific surface area of the Biofield Energy Treated metronidazole powder $(0.0262$ $\mathrm{m}^{2} / \mathrm{g}$ ) was significantly decreased by $10.58 \%$ compared to the control sample $\left(0.0262 \mathrm{~m}^{2} / \mathrm{g}\right)$. It can be presumed that the Trivedi Effect ${ }^{\circ}$ Consciousness Energy Healing Treatment might be responsible for increasing the smaller particles to larger particles of metronidazole powder sample, thus decreasing the surface area. It was reported that the particle size, shape, and surface area impact the powder flow ability, stability, solubility, dissolution rate, absorption, bioavailability, and therapeutic efficacy of a drug [38,39]. Thus, it was expected that the Biofield Energy Treated metronidazole sample might offer better powder flow ability, good stability, and rapid dissolving rate compared to the control sample.

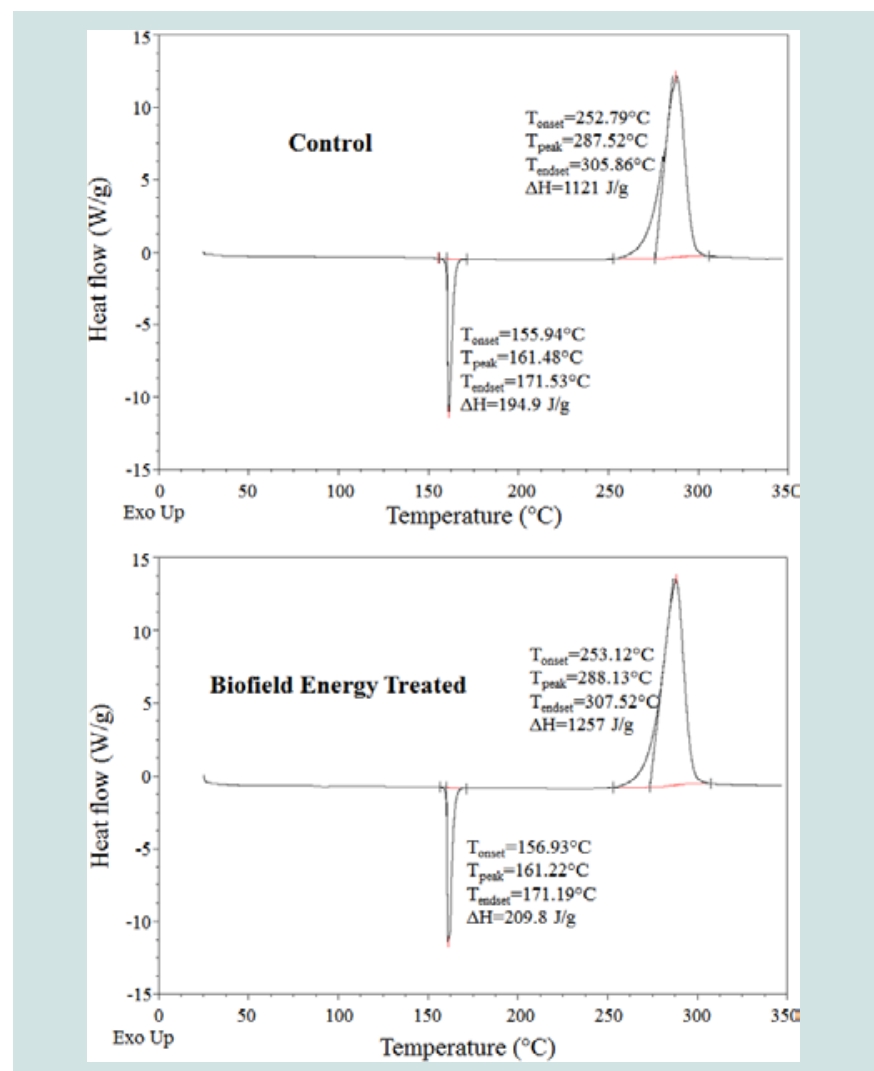

Figure 2: DSC thermograms of the control and the Biofield Energy Treated metronidazole powder sample. 
Citation: Trivedi D, Trivedi MK, Branton A, Nayak G, Jana S. Influence of the Biofield Energy Healing Treatment on the Physicochemical and Thermal Properties of Metronidazole. J Analyt Molecul Tech 2018;3(1): 7.

ISSN: $2474-1914$

Table 2: PXRD data for the control and the Biofield Energy Treated metronidazole powder sample.

\begin{tabular}{|c|c|c|c|c|c|c|c|c|}
\hline \multirow{2}{*}{ Entry No. } & \multicolumn{2}{|c|}{ Bragg angle $\left({ }^{\circ} 2\right)$} & \multicolumn{3}{|c|}{ Peak Intensity (\%) } & \multicolumn{3}{|c|}{ Crystallite size (G, nm) } \\
\hline & Control & Treated & Control & Treated & $\%$ change $^{a}$ & Control & Treated & $\%$ change $^{b}$ \\
\hline 1 & 6.29 & 6.49 & 51 & 60 & 17.65 & 178 & 200 & 12.36 \\
\hline 2 & 12.28 & 12.64 & 8172 & 5876 & -28.10 & 503 & 480 & -4.57 \\
\hline 3 & 13.86 & 14.13 & 1211 & 713 & -41.12 & 458 & 460 & 0.44 \\
\hline 4 & 16.22 & 16.55 & 70 & 87 & 24.29 & 507 & 350 & -30.97 \\
\hline 5 & 17.10 & 17.51 & 226 & 189 & -16.37 & 167 & 319 & 91.02 \\
\hline 6 & 19.43 & 19.55 & 114 & 70 & -38.60 & 390 & 144 & -63.08 \\
\hline 7 & 20.25 & 20.44 & 106 & 33 & -68.87 & 124 & 551 & 344.35 \\
\hline 8 & 21.52 & 21.84 & 609 & 443 & -27.26 & 400 & 731 & 82.75 \\
\hline 9 & 23.15 & 23.55 & 61 & 106 & 73.77 & 447 & 269 & -39.82 \\
\hline 10 & 25.38 & 25.53 & 253 & 396 & 56.52 & 346 & 445 & 28.61 \\
\hline 11 & 27.24 & 27.61 & 299 & 309 & 3.34 & 273 & 336 & 23.08 \\
\hline 12 & 29.23 & 29.07 & 1017 & 28 & -97.25 & 518 & 697 & 34.56 \\
\hline 13 & 29.67 & 29.61 & 305 & 1530 & 401.64 & 298 & 844 & 183.22 \\
\hline 15 & 33.80 & 33.60 & 220 & 294 & 33.64 & 323 & 485 & 50.15 \\
\hline 16 & 43.14 & 43.68 & 69 & 86 & 24.64 & 195 & 206 & 5.64 \\
\hline 17 & 46.52 & 46.96 & 123 & 149 & 21.14 & 197 & 226 & 14.72 \\
\hline 18 & \multicolumn{5}{|c|}{ Average crystallite size } & 340.41 & 423.47 & 24.40 \\
\hline
\end{tabular}

${ }^{a}$ denotes the percentage change in the peak intensity of the Biofield Energy Treated sample with respect to the control sample; ${ }^{b}$ denotes the percentage change in the crystallite size of the Biofield Energy Treated powder sample with respect to the control samplea.

Table 3: DSC data for both control and the Biofield Energy Treated samples of metronidazole powder sample.

\begin{tabular}{|c|c|c|c|}
\hline Sample & Melting Temp $\left({ }^{\circ} \mathbf{C}\right)$ & Decomposition Temp ( $\left.{ }^{\circ} \mathbf{C}\right)$ & \multicolumn{2}{|c|}{$\Delta \mathbf{H}(\mathbf{J} / \mathbf{g})$} \\
\hline Control Sample & 161.48 & 287.52 & 194.90 \\
\hline Biofield Energy Treated & 161.22 & 288.13 & 1121.00 \\
\hline \% Change* & -0.16 & 0.21 & 1257.00 \\
\hline
\end{tabular}

$\Delta \mathrm{H}$ : Latent heat of fusion/decomposition, *denotes the percentage change of the Biofield Energy Treated metronidazole with respect to the control sample.

\section{Powder X-ray diffraction (PXRD) analysis}

The PXRD diffractogram of the control metronidazole powder sample shown sharp and intense peaks at Bragg's angle $(2 \theta)$ equal to $6.29^{\circ}, 12.28^{\circ}, 13.86^{\circ}, 16.22^{\circ}, 17.1^{\circ}, 19.43^{\circ}, 20.25^{\circ}, 21.52^{\circ}, 23.15^{\circ}$, $25.38^{\circ}, 27.24^{\circ}, 29.23^{\circ}, 29.67^{\circ}, 33.01^{\circ}, 33.8^{\circ}, 43.14^{\circ}$, and $46.52^{\circ}$ (Figure 1). Correspondingly, the Biofield Energy Treated metronidazole showed the peaks at Bragg's angle $(2 \theta)$ equal to $6.49^{\circ}, 12.64^{\circ}, 14.13^{\circ}$, $16.55^{\circ}, 17.51^{\circ}, 19.55^{\circ}, 20.44^{\circ}, 21.84^{\circ}, 23.55^{\circ}, 25.53^{\circ}, 27.61^{\circ}, 29.07^{\circ}$, $29.61^{\circ}, 33.28^{\circ}, 33.6^{\circ}, 43.68^{\circ}$, and $46.96^{\circ}$ (Figure 1). The sharp and intense peaks in the diffractograms indicated that both the samples were crystalline. The control and the Biofield Energy Treated sample showed the highest peak intensity at $2 \theta$ equal to $12.28^{\circ}$ and $12.64^{\circ}$, respectively (Table 2, entry 2). The peak intensities of the Biofield Energy Treated metronidazole were significantly altered ranging from $-97.25 \%$ to $401.64 \%$ compared to the control sample. Likewise, the crystallite sizes of the Biofield Energy Treated metronidazole powder sample were significantly altered ranging from $-63.08 \%$ to $344.35 \%$ compared to the control sample. Hence, the average crystallite size of the Biofield Energy Treated metronidazole powder sample (423.47 $\mathrm{nm}$ ) was significantly increased by $24.4 \%$ compared to the control sample $(340.41 \mathrm{~nm})$.

The alteration in the crystallite sizes and peak intensities indicated the change in the crystal morphology of the Biofield Energy Treated metronidazole powder compared to the control sample. The peak intensity of each diffraction face on the crystalline compound changes according to the crystal morphology and alterations in the
XRD pattern provide proof of polymorphic transitions [40-42]. The Trivedi Effect ${ }^{\circ}$-Consciousness Energy Healing Treatment probably responsible for the production of a new polymorphic form of metronidazole through the mediation of neutrino oscillations [18]. Altered polymorphic forms of pharmaceuticals have a significant effect on the drug performance, such as bioavailability, therapeutic efficacy, and toxicity, because of their different thermodynamic and physicochemical properties from the original one [43]. Hence, it can be assumed that the Biofield Energy Treated metronidazole would be better in designing more effective pharmaceutical formulations.

\section{Differential scanning calorimetry (DSC) analysis}

The thermograms of the control and the Biofield Energy Treated metronidazole samples showed the sharp endothermic peak at 161.48 ${ }^{\circ} \mathrm{C}$ and $161.22^{\circ} \mathrm{C}$, respectively (Figure 2). Similarly, both the control and the Biofield Energy Treated samples showed exothermic peaks at $287.52{ }^{\circ} \mathrm{C}$ and $288.13{ }^{\circ} \mathrm{C}$, respectively (Figure 2). The experimental data closely matched to the literature reported data [10]. The melting point and decomposition temperature of the Biofield Energy Treated samples were altered by $-0.16 \%$ and $0.21 \%$, respectively compared with the control sample (Table 3). The latent heat of fusion $\left(\Delta \mathrm{H}_{\text {fusion }}\right)$ and latent heat of decomposition $\left(\Delta \mathrm{H}_{\text {decomposition }}\right)$ of the Biofield Energy Treated metronidazole were significantly increased by $7.64 \%$ and $12.13 \%$ compared with the control sample (Table 3). The melting point has been reported to increase with increasing particle size [44, 45]. The particle size data justified the decreased thermal properties of the Biofield Energy Treated metronidazole compared to the control sample. 

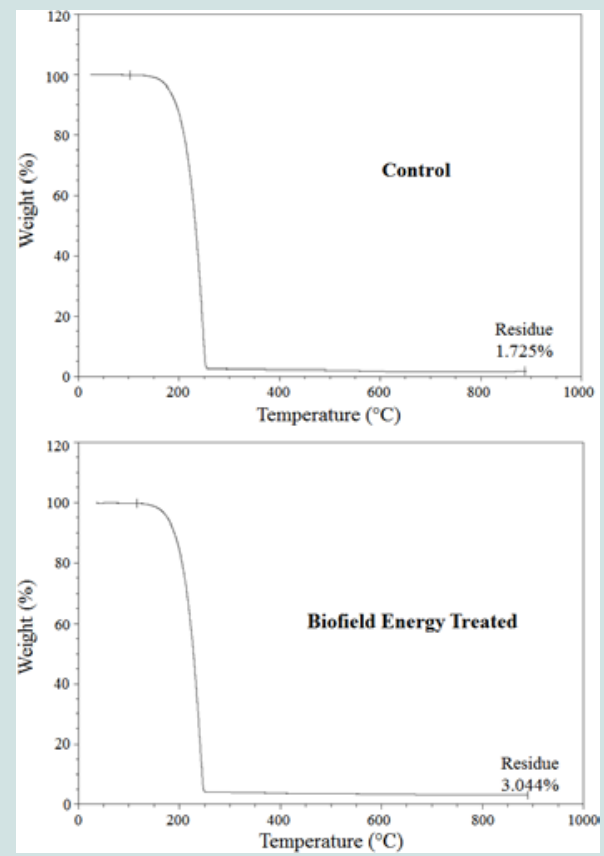

Figure 3: TGA thermograms of the control and the Biofield Energy Treated metronidazole powder sample.

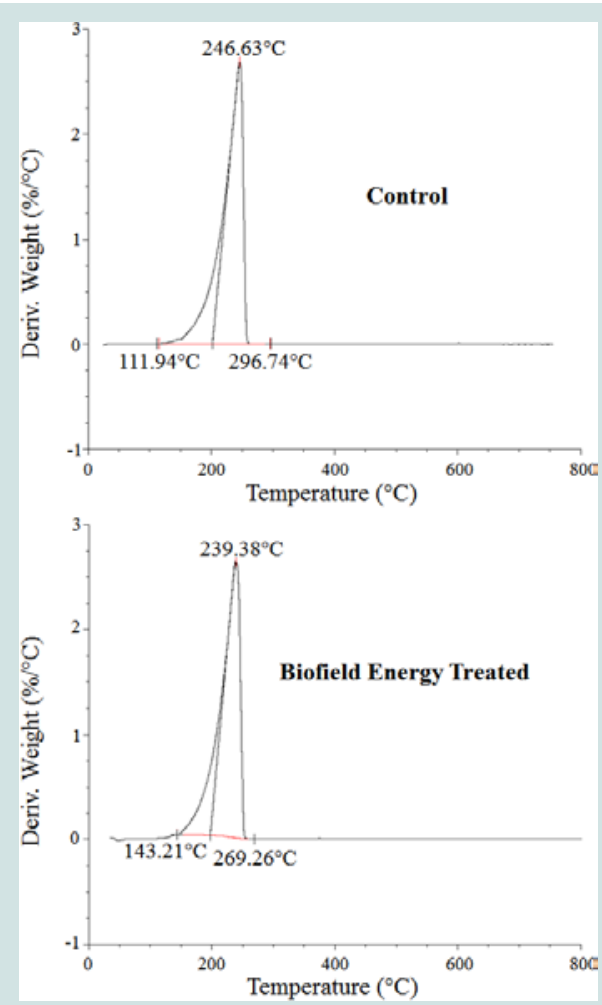

Figure 4: TGA thermograms of the control and the Biofield Energy Treated metronidazole powder sample.

As per the literature, any change in the latent heat of fusion can be attributed to the disrupted molecular chains and the crystal structure [46]. Thus, it can be assumed that the Trivedi Effect ${ }^{\circ}$-Consciousness
Table 4: TGA/DTG data of the control and Biofield Energy Treated samples of metronidazole powder sample.

\begin{tabular}{|c|c|c|c|}
\hline \multirow{2}{*}{ Sample } & \multicolumn{2}{|c|}{ TGA } & DTG \\
\cline { 2 - 4 } & Total weight loss (\%) & Residue \% & T $_{\max }\left({ }^{\circ} \mathbf{C}\right)$ \\
\hline Control & 98.275 & 1.725 & 246.63 \\
\hline Biofield Energy Treated & 96.956 & 3.044 & 239.38 \\
\hline$\%$ Change* & -1.34 & 76.46 & -2.94 \\
\hline
\end{tabular}

*denotes the percentage change of the Biofield Energy Treated sample with respect to the control sample.

${ }^{\top} \max =$ the temperature at which maximum weight loss takes place in TG or peak temperature in DTG.

Energy Healing Treatment might have altered the molecular chains and crystal structure of the Biofield Energy Treated metronidazole molecule so that the thermal stability of the treated sample was increased compared with the control sample.

\section{Thermal gravimetric analysis (TGA)/ Differential thermogravimetric analysis (DTG)}

The control and the Biofield Energy Treated samples showed one step of thermal degradation in the TGA thermograms (Figure 3). The total weight loss of the Biofield Energy Treated metronidazole sample was decreased by $1.34 \%$ more compared to the control sample (Table 4). Therefore, the residue amount was significantly increased by $76.46 \%$ in the Biofield Energy Treated sample compared to the control sample (Table 4).

The DTG thermograms of the control and the Biofield Energy Treated sample also showed one peak in the thermograms (Figure 4). The maximum thermal degradation temperature $\left(\mathrm{T}_{\max }\right)$ of the Biofield Energy Treated sample was decreased by $2.94 \%$ compared to the control sample (Table 4). Hence, the overall TGA/DTG results of metronidazole powder samples revealed that the thermal stability of the Biofield Energy Treated sample was increased compared to the control sample.

\section{Conclusion}

The Trivedi Effect ${ }^{\oplus}$-Consciousness Energy Healing Treatment has shown a significant effect on the particle size, surface area, crystallite size, and thermal properties of metronidazole. The particle size values in the Biofield Energy Treated metronidazole powder sample were significantly increased by $14.37 \%, 9.94 \%, 7.9 \%$, and $9.41 \%$ at $\mathrm{d}_{10}$, $\mathrm{d}_{50}, \mathrm{~d}_{90}$, and $\mathrm{D}(4,3)$ compared to the control sample. Therefore, the specific surface area of the Biofield Energy Treated powder sample was significantly decreased by $10.58 \%$ compared to the control sample. The PXRD peak intensities and crystallite sizes of the Biofield Energy Treated powder sample were significantly altered ranging from $-97.25 \%$ to $401.64 \%$ and $-63.08 \%$ to $344.35 \%$, respectively compared to the control sample. The average crystallite size of the Biofield Energy Treated metronidazole powder was significantly increased by $24.4 \%$ compared with the control sample. The melting and decomposition temperature of the Biofield Energy Treated sample slightly altered compared with the control sample. However, the $\Delta \mathrm{H}_{\text {fusion }}$ and $\Delta \mathrm{H}_{\text {decomposition }}$ were significantly increased by $7.64 \%$ and $12.13 \%$ in the treated sample compared with the control sample. The total weight loss was decreased by $1.34 \%$; however, the residue amount was significantly increased by $76.46 \%$ in the treated sample compared with the control sample. The $\mathrm{T}_{\max }$ was altered by $2.94 \%$ in the treated sample compared with the control sample. Therefore, the 
Citation: Trivedi D, Trivedi MK, Branton A, Nayak G, Jana S. Influence of the Biofield Energy Healing Treatment on the Physicochemical and Thermal Properties of Metronidazole. J Analyt Molecul Tech 2018;3(1): 7

Trivedi Effect ${ }^{\circledR}$-Consciousness Energy Healing Treatment might lead to generate a new polymorphic form of metronidazole which would offer better powder flow ability, good stability, rapid-dissolving rate, and thermally more stable compared with the control sample. The Trivedi Effect ${ }^{\circledR}$-Consciousness Energy Healing Treated metronidazole sample would be very useful in designing better pharmaceutical formulations that might offer better therapeutic responses against the bacterial infections in vagina (trichomoniasis), stomach infections (pseudomembranous colitis, giardiasis), liver, skin, joints (pelvic inflammatory disease, abscess of the ovaries and fallopian tubes), brain, and respiratory tract, aspiration pneumonia, wounds, rosacea, intra-abdominal infections, lung abscess, periodontitis, amoebiasis, oral infections, and other infections caused by the anaerobic microorganisms such as Bacteroides, Clostridium, Helicobacter pylori, Fusobacterium, Dracunculus, Peptostreptococcus, and Prevotella species, etc.

\section{References}

1. Metronidazole (2018) The American society of health-system pharmacists.

2. Freeman CD, Klutman NE, Lamp KC (1997) Metronidazole. A therapeutic review and update. Drugs 54: 679-708.

3. Joesoef MR, Schmid GP, Hillier SL (1999) Bacterial vaginosis: Review of treatment options and potential clinical indications for therapy. Clin Infect Dis 1: S57-S65.

4. Shennan A, Crawshaw S, Briley A, Hawken J, Seed P, et al. (2006) A randomised controlled trial of metronidazole for the prevention of preterm birth in women positive for cervicovaginal fetal fibronectin: The PREMET Study. BJOG 113: 65-74.

5. Zar FA, Bakkanagari SR, Moorthi KM, Davis MB (2007) A comparison of vancomycin and metronidazole for the treatment of Clostridium difficileassociated diarrhea, stratified by disease severity. Clin Infect Dis 45: $302-$ 307.

6. Barr SC, Bowman DD, Heller RL (1994) Efficacy of fenbendazole against giardiasis in dogs. Am J Vet Res 55: 988-990.

7. Aditya BA, Srikanth A, Sriranga LG (2013) Metronidazole induced cerebellar ataxia. Indian J Pharmacol 45: 295-297.

8. Kling PA, Burman LG (1989) Serum and tissue pharmacokinetics of intravenous metronidazole in surgical patients. Acta Chir Scand 155:347-350.

9. Martin C, Sastre B, Mallet MN, Bruguerolle B, Brun JP, et al. (1991) Pharmacokinetics and tissue penetration of a single 1,000-milligram, intravenous dose of metronidazole for antibiotic prophylaxis of colorectal surgery. Antimicrob Agents Chemother 35: 2602-2605.

10. Chien YW (1984) Solubilization of metronidazole by water-miscible multicosolvents and water-soluble vitamins. J Pharenter Sci Technol 38: 32-36.

11. Garmroodi A, Hassan J, Yamini Y (2004) Solubilities of the drugs benzocaine, metronidazole benzoate, and naproxen in supercritical carbon dioxide. J Chem Eng Data 49: 709-712.

12. Chereson R (2009) Bioavailability, bioequivalence, and drug selection. In Makoid CM, Vuchetich PJ, Banakar UV (Eds) Basic pharmacokinetics ( $1^{\text {st }}$ Edn) Pharmaceutical Press, London.

13. Trivedi MK, Patil S, Shettigar H, Bairwa K, Jana S (2015) Effect of biofield treatment on spectral properties of paracetamol and piroxicam. Chem Sci J 6: 98.

14. Branton A, Jana S (2017) Effect of The biofield energy healing treatment on the pharmacokinetics of 25-hydroxyvitamin $\mathrm{D}_{3}\left[25(\mathrm{OH}) \mathrm{D}_{3}\right]$ in rats after a single oral dose of vitamin $D_{3}$. Am J Pharmacol Phytother 2: 11-18.

15. Trivedi MK, Patil S, Shettigar H, Bairwa K, Jana S (2015) Spectroscopic characterization of biofield treated metronidazole and tinidazole. Med chem 5: $340-344$.
16. Trivedi MK, Branton A, Trivedi D, Nayak G, Nykvist CD, et al. (2017) Evaluation of the Trivedi Effect ${ }^{\circledR}$ - Energy of Consciousness Energy Healing Treatment on the physical, spectral, and thermal properties of zinc chloride. Am J Life Sci 5: 11-20.

17. Trivedi MK, Branton A, Trivedi D, Nayak G, Wellborn BD, et al. (2017) Characterization of physicochemical, thermal, structural, and behavioral properties of magnesium gluconate after treatment with the energy of consciousness. Int J Phar Chem 3: 1-12.

18. Trivedi MK, Mohan TRR (2016) Biofield energy signals, energy transmission and neutrinos. Am J Mod Phys 5: 172-176.

19. Rubik B, Muehsam D, Hammerschlag R, Jain S (2015) Biofield science and healing: history, terminology, and concepts. Glob Adv Health Med 4: 8-14.

20. Barnes PM, Bloom B, Nahin RL (2008) Complementary and alternative medicine use among adults and children: United States, 2007. Natl Health Stat Report 12: 1-23.

21. Koithan M (2009) Introducing complementary and alternative therapies. J Nurse Pract 5: 18-20.

22. Trivedi MK, Branton A, Trivedi D, Nayak G, Panda P, et al. (2016) Gas chromatography-mass spectrometric analysis of isotopic abundance of ${ }_{13} \mathrm{C}$, ${ }_{2} \mathrm{H}$, and ${ }_{18} \mathrm{O}$ in biofield energy treated p-tertiary butylphenol (PTBP). Am J Chem Eng 4: 78-86.

23. Trivedi MK, Branton A, Trivedi D, Nayak G, Sethi KK, et al. (2016) Gas chromatography-mass spectrometry based isotopic abundance ratio analysis of biofield energy treated methyl-2-napthylether (Nerolin). Am J Phys Chem 5: 80-86.

24. Trivedi MK, Tallapragada RM, Branton A, Trivedi D, Nayak G, et al. (2015) Characterization of physical and structural properties of aluminium carbide powder: impact of biofield treatment. J Aeronaut Aerospace Eng 4: 142.

25. Trivedi MK, Nayak G, Patil S, Tallapragada RM, Mishra R (2015) Influence of biofield treatment on physicochemical properties of hydroxyethyl cellulose and hydroxypropyl cellulose. J Mol Pharm Org Process Res 3: 126.

26. Trivedi MK, Nayak G, Patil S, Tallapragada RM, Latiyal O (2015) Studies of the atomic and crystalline characteristics of ceramic oxide nano powders after bio field treatment. Ind Eng Manage 4: 161.

27. Trivedi MK, Branton A, Trivedi D, Shettigar H, Nayak G, et al. (2015) Antibiogram typing of biofield treated multidrug resistant strains of Staphylococcus species. Am J Life Sci 3: 369-374.

28. Trivedi MK, Branton A, Trivedi D, Shettigar H, Nayak G, et al. (2015) Antibiogram, biochemical reactions and genotyping characterization of biofield treated Staphylococcus aureus. American Journal of BioScience 3: pp. 9.

29. Trivedi MK, Patil S, Shettigar H, Mondal SC, Jana S (2015) The potential impact of biofield treatment on human brain tumor cells: A time-lapse video microscopy. J Integr Oncol 4: 141.

30. Trivedi MK, Patil S, Shettigar H, Gangwar M, Jana S (2015) In vitro evaluation of biofield treatment on cancer biomarkers involved in endometrial and prostate cancer cell lines. J Cancer Sci Ther 7: 253-257.

31. Trivedi MK, Branton A, Trivedi D, Nayak G, Gangwar M, et al. (2015) Agronomic characteristics, growth analysis, and yield response of biofield treated mustard, cowpea, horse gram, and groundnuts. Int J Genetics Genomics 3: 74-80.

32. Trivedi MK, Branton A, Trivedi D, Nayak G, Mondal SC, et al. (2015) Evaluation of plant growth, yield and yield attributes of biofield energy treated mustard (Brassica juncea) and chick pea (Cicer arietinum) seeds. Agric Forestry Fisheries 4: 291-295.

33. Trivedi MK, Sethi KK, Panda P, Jana S (2017) A comprehensive physicochemical, thermal, and spectroscopic characterization of zinc (II) chloride using X-ray diffraction, particle size distribution, differential scanning calorimetry, thermogravimetric analysis/differential thermogravimetric analysis, ultraviolet-visible, and Fourier transform-infrared spectroscopy. Int J Pharm Investig 7: 33-40. 
Citation: Trivedi D, Trivedi MK, Branton A, Nayak G, Jana S. Influence of the Biofield Energy Healing Treatment on the Physicochemical and Thermal Properties of Metronidazole. J Analyt Molecul Tech 2018;3(1): 7.

\section{ISSN: $2474-1914$}

34. Trivedi MK, Sethi KK, Panda P, Jana S (2017) Physicochemical, thermal and spectroscopic characterization of sodium selenate using XRD, PSD, DSC, TGA/DTG, UV-vis, and FT-IR. Marmara Pharm J 21: 311-318.

35. (1997) Desktop X-ray Diffractometer “MiniFlex+”. The Rigaku Journal 14: 29-36.

36. Zhang T, Paluch K, Scalabrino G, Frankish N, Healy AM, et al. (2015) Molecular structure studies of (1S,2S)-2-benzyl-2,3-dihydro-2-(1Hinden-2 yl)-1H-inden-1-ol. J Mol Struct 1083: 286-299.

37. Langford JI, Wilson AJ (1978) Scherrer after sixty years: A survey and some new results in the determination of crystallite size. J Appl Cryst 11: 102-113.

38. Mosharrof M, Nystrom C (1995) The effect of particle size and shape on the surface specific dissolution rate of microsized practically insoluble drugs. Int J Pharm 122: 35-47.

39. Buckton G, Beezer AE (1992) The relationship between particle size and solubility. Int J Pharm 82: R7-R10.

40. Raza K, Kumar P, Ratan S, Malik R, Arora S (2014) Polymorphism: The phenomenon affecting the performance of drugs. SOJ Pharm Pharm Sci 1: 10.
41. Brittain HG (2009) Polymorphism in pharmaceutical solids. In: Drugs and pharmaceutical sciences, ( $2^{\text {nd }}$ edn) Informa Healthcare USA, Inc., New York 192.

42. Censi R, Di Martino P (2015) Polymorph Impact on the Bioavailability and Stability of Poorly Soluble Drugs. Molecules 20: 18759-18776.

43. Blagden N, de Matas M, Gavan PT, York P (2007) Crystal engineering of active pharmaceutical ingredients to improve solubility and dissolution rates. Adv Drug Deliv Rev 59: 617-630.

44. Chereson R (2009) Bioavailability, bioequivalence, and drug selection. In Makoid CM, Vuchetich PJ, Banakar UV (eds). Basic pharmacokinetics (1 ${ }^{\text {st }}$ edn) Pharmaceutical Press, London.

45. Antoniammal P, Arivuoli D (2012) Size and shape dependence on melting temperature of gallium nitride nanoparticles. J Nanomater 2012: pp. 11.

46. Zhao Z, Xie M, Li Y, Chen A, Li G, et al. (2015) Formation of curcumin nanoparticles via solution-enhanced dispersion by supercritical CO2. Int J Nanomedicine 10: 3171-3181.

\section{Acknowledgement}

The authors are grateful to Central Leather Research Institute, SIPRA Lab. Ltd., Trivedi Science, Trivedi Global, Inc., Trivedi Testimonials, and Trivedi Master Wellness for their assistance and support during this work. 